\title{
On the interconnectedness of regulatory policy and markets lessons from banking
}

\section{Working Paper}

Author(s):

Bernauer, Thomas; Koubi, Vally

Publication date:

2005

Permanent link:

https://doi.org/10.3929/ethz-a-004907503

Rights / license:

In Copyright - Non-Commercial Use Permitted

Originally published in:

CIS working paper 2005(5) 
Published by the Center for Comparative and International Studies (ETH Zurich and University of Zurich)

\section{On the Interconnectedness of}

\section{Regulatory Policy and Markets:}

\section{Lessons from Banking}

by Thomas Bernauer and Vally Koubi

CIS

ETH Zurich 


\title{
On the Interconnectedness of Regulatory Policy and Markets: Lessons from Banking
}

\author{
Thomas Bernauer and Vally Koubi \\ Center for Comparative and International Studies (CIS) \\ Swiss Federal Institute of Technology (ETH Zurich)
}




\section{Contents}

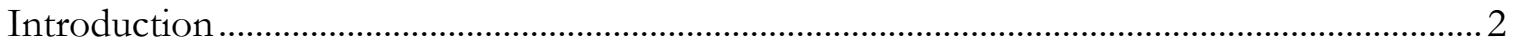

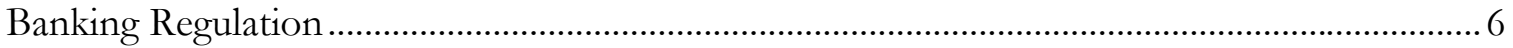

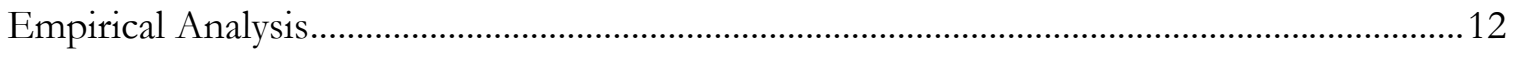

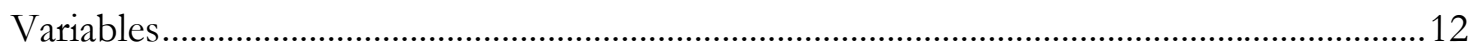

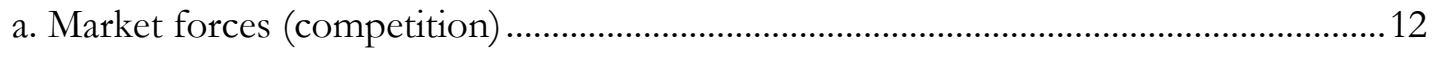

b. Regulatory measures and other types of government intervention ..............................13

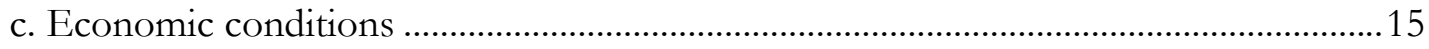

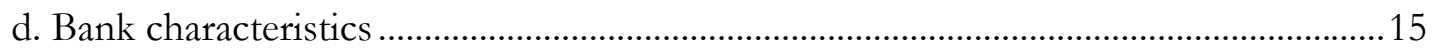

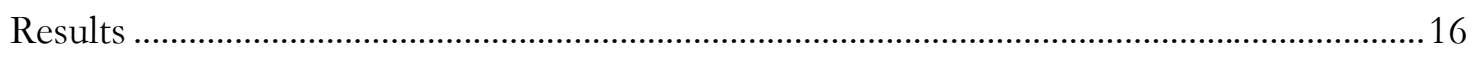

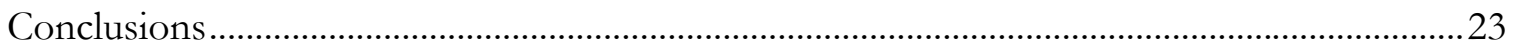

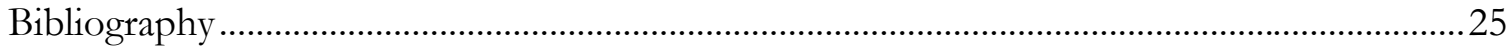




\section{Introduction}

The ways in which the increasing integration of the world economy, particularly since the mid-1970s, are shaping the roles of governments and markets have been subjects of intensive debate in the international and comparative political economy literature (e.g., Thatcher 2004; Gilpin 2001; Hall and Soskice 2001; Berger 2000; Cerny 1990; 2005; Kitschelt et al. 1999; Strange 1998; Underhill 1997; Porter 1993; Berger and Dore 1996). The role of markets has certainly expanded in recent years, as exemplified by the widespread privatization of formerly state run enterprises. Leading examples include the telecom and electric power sectors, postal services, the airline industry, water supply, waste management, financial services, and so on. But this development has not necessarily led to a diminished role for the state since reductions in the direct production or provision of goods and services by governments have been accompanied by the introduction of new and the expansion of existing domestic and international regulation.

As both markets and regulation expand some observers argue that globalization is transforming advanced OECD countries into "regulatory states", in the sense that they are moving towards "freer markets, more rules" (Vogel 1998; see also Jordana and Levi-Faur 2004 and Majone 1996). A number of important questions have thus emerged regarding the nature and implications of this trend. These questions are at the heart of important debates in the globalization, regulatory policy, and varieties of capitalism literature (e.g., Thatcher 2004; Hall and Soskice 2001; Berger 2000; Kitschelt et al. 1999; Berger and Dore 1996). Does the trend just referred to pull economies and polities in the same or in different directions? Do markets and regulation reinforce each other, or are their effects independent or countervailing? In what kind of areas are we more likely to witness synergies between regulatory policy and market forces? Under what conditions could markets forces render regulation redundant? How does the relation between regulation and market processes affect the prospects for international policy coordination or convergence?

Regulation can be a bland instrument with significant, adverse side effects on economic performance. Providing then answers to these questions may prove useful for designing more effective regulation, that is, regulation that exploits favorable market reaction to achieve its objectives at a lower cost (for instance, inducing self policing by the markets 
and hence reducing costly monitoring by the regulators). There are several issues that are at center stage in national and international policy debates (international banking regulation, global accounting standards, the harmonization of environmental and labor standards, and so on) that could benefit from the study of the questions presented above. While some of them have been individually and informally addressed, a systematic, empirical treatment that would identify and highlight the factors that are involved in the interconnection between markets and regulation and would carry useful insights for a more general set of situations is still missing.

In this paper we contribute to filling this gap in the context of a well-defined and practically important case, namely banking. We have chosen banking because this sector has four appealing features: first, data has recently become available for a relatively large number of countries and banks. Second, the banking sector is subject to both national and international regulation. Third, national and international regulation and private firm decisions are closely connected. And fourth, the banking industry has been strongly affected by globalization. The first feature means that the empirical tools available to social scientists can be fruitfully applied, so that the analysis can be based on a rigorous methodological framework. The second, third and forth features imply that the findings of this study may be relevant for other issue areas with similar characteristics.

We take advantage of data that has recently become available to examine how regulation and market forces affect the decisions of banks with regard to how much capital to hold. The purpose of regulating bank capital - i.e., prescribing minimum levels of capital that banks must hold against loans they make - has been to minimize bank solvency and liquidity problems that may destabilize national and international financial systems. Banks with more capital are less likely to fail. We seek to explain the variation in capitalization across banks and countries by focusing on four sets of variables: market pressure (competition), properties of national regulatory regimes (direct effects of regulation), general economic conditions, and individual bank characteristics. Our analysis of 1267 banks from 29 OECD countries in 1999 shows that market pressure (competition) promotes bank capitalization. The direct effect of regulation, measured in terms of regulatory power and stringency, seems ambiguous. The latter finding, however, does not necessarily imply that regulation is less effective than markets in promoting policy objectives. We will argue that some of the 
positive effect on bank capitalization attributed to market forces may have been triggered or supported by suitable regulation.

These findings are useful for understanding how certain types of international regulation, such as the Basle Accord", may almost "painlessly" come into existence and spread internationally. These findings also help in understanding how such regulation can succeed in reducing global financial systemic risk even when it appears that the constraints they have imposed on bank behavior are non-binding. By non-binding we refer to the pattern documented below that banks systematically and significantly over-comply with regulatory requirements.

We believe that the synergies contained in the relationship between regulatory and market forces are crucial to understanding the aforementioned phenomena. By synergy we mean that regulatory policy and market forces each reinforces the effect of the other. Our view is that the Basle Accord and the minimum capitalization standards it prescribes spread quickly and with relatively small resistance because the key postulates of this regulation were, on average, consistent with individual bank incentives. The main element of the Basle Accord was not the imposition of minimum capital requirements per se, but rather how the Accord transformed the banking market. In particular, it increased transparency and hence competition by demanding that banks adhere to well defined capital requirements, which are reported publicly and are easily comparable across countries. The increased market pressure that followed the introduction of this regulation promoted compliance and even overcompliance as banks rushed to raise capital levels in order to signal their quality. These mutually reinforcing effects of regulation and competition seem to have achieved outcomes that go beyond the level playing field situation which at the outset of the cooperative process may have played a role in motivating US regulators to push for multilateral rules (Genschel and Plümper 1997).

Our findings may also prove useful for studying the issue of regulatory convergencedivergence in open world markets. As noted above, many proposals for stricter national and international standards in areas ranging from environmental performance and taxation of multinational firms to corporate governance and accounting standards are currently being

1 The Basle Accord, reached in 1988, provides for the uniform measurement of bank capital and specifies minimum capital levels banks must hold against risk-weighed assets (such as credits to firms or countries). 
debated. Our analysis suggests that effective international standards in these areas are more likely to emerge when they do not contradict competitive forces, when market pressure is strong and/or can be enhanced through transparency-creating regulation, and when these forces are present across countries. Under such conditions suitable international standards will encourage economic actors in various countries to signal superior quality to their respective markets by complying or even over-complying with environmental, corporate governance, accounting, or other standards.

An example from another area of international regulation, namely, corporate accounting standards, illustrates this proposition. To the extent that corporate scandals (e.g., Enron and Parmalat) have sensitized global markets, firms have a strong incentive to adopt greater transparency and best practice accounting standards in order to lower their borrowing costs and/or draw funds from global equity markets. That is, firms can signal their quality to financial markets by adopting more transparent and stringent standards. The fact that the most important firms in a large number of countries and industries are linked to global financial markets implies that such incentives are present throughout the world economy. Regulators can trigger and/or enhance this process by selecting the appropriate set of standards. To the extent that the appropriate standards are similar across countries there will be a tendency for international policy convergence and market forces will further promote convergence.

The remainder of the paper is organized as follows. Section 2 describes the main issue in the context of the banking industry and reviews the literature. Section 3 carries out the empirical analysis and presents the results. Section 4 concludes. 


\section{Banking Regulation}

Government regulation is commonly justified by the presence of market failures emanating from public goods, externalities, monopolies, or information asymmetries between buyers and sellers. In the case of banking, regulation is usually justified on the grounds that bank lenders are unable to monitor their banks' financial soundness (asymmetric information) and that there is a risk of systemic crisis (notably, bank failures creating bank runs ${ }^{2}$ ).

Such problems may, in principle, be prevented by a variety of measures, including the introduction of "narrow banking" (i.e., creation of banks that invest only in low-risk securities), equity funded rather than demand deposit funded banks, government deposit insurance, and so on. Although these measures may insulate banks from runs, they have serious drawbacks. For example, they may lead to moral hazard ${ }^{3}$, as may be the case with deposit insurance. In view of these disadvantages, requiring banks to increase their capital base has, since the late 1980s, emerged as a popular regulatory response to the risk of systemic crisis ${ }^{4}$. High capitalization is widely perceived to improve the soundness and safety of the banking sector without compromising economic performance. Indeed, requiring banks to hold higher levels of capital may reduce banks' incentives to take high risks since bank shareholders have more to lose if their bank fails and hence they will keep a tighter watch on the activities of the bank.

Since the mid-1970s we have witnessed a dramatic increase in the extent of integration of global financial markets. Virtually in parallel we observe expanding national and international regulatory efforts in this area. The most prominent such effort to date has been the Basle Accord and its revisions. The Basle Accord was adopted in July 1988 and fully implemented from December 1992 on. It applies to credit risk, harmonizes the measurement of bank capital, and mandates minimum ratios of bank capital to risk-weighed bank assets.

2 This is an externality problem, where some poorly capitalized banks undermine public confidence in the entire banking system and cause bank runs that also affect well-capitalized banks.

3 Moral hazard, in this context, means that the insurance of deposits may induce banks to engage in more risky investments than they would in the absence of insurance.

4 See Berger et al (1995) for the role of capital in financial institutions and Santos (2000) for a review of the literature on bank capital regulation. 
Its goals were (and still are) to reduce risks in the international banking system and to minimize competitive inequality ${ }^{5}$ arising from differences among national bank-capital regulations. Several additions to and revisions of the Basle Accord have been adopted since 1988. The most important such revision, the so-called Basle II Accord, was adopted in 2003 and will enter into force at the end of 2006. In this paper we concentrate on the Basle standards currently in force.

The Basle Accord aims at defining and enforcing minimum levels for risk-weighed capital-asset ratios of banks. That is, regulators have prescribed the amount of capital that banks must hold against specific types of risky assets (e.g., credits to firms or countries). The Accord has established a common international definition of bank capital that divides capital into two tiers. Tier 1 capital is common to all signatory countries and consists of common stockholder equity and disclosed reserves (except for some forms of preferred stock that U.S. bank holding companies also include). Tier 2 capital, which consists of leeway elements that at least one of the signatory countries considers to be bank capital, can include any combination of eligible capital elements permitted by national regulators. Assets are weighted by a risk factor (e.g., 0 for government bonds, 1 for credits extended to companies, and so on). Assets defined as less risky require less bank capital. The minimum capital of banks as mandated by the Basle Accord is 8 percent (Tier1 + Tier $2=8 \%$ ), with at least half of this ratio to be met by Tier 1 capital (Tier $1=4 \%$ ).

Political scientists have devoted considerable efforts to explaining the initiation and diffusion of the Basle Accord. Earlier work has emphasized an "international regimes" perspective. More generically, with reference to political and economic interests and power they have thus tried to explain when and why states succeed in imposing national and/or international regulation in open global markets where many observers expect fierce competition among firms to undermine regulatory efforts. Kapstein (1989, 1992, 1994) focuses on the influence of knowledge and power (see also Strange, 1998 and Porter, 1993). He argues that the Basle Accord came about from a perception of the existence of a

5 Wagster (1996) argues, however, that the Basle Accord did not minimize competitive inequality because it failed to address a funding-cost advantage of Japanese banks. 
common problem, a common view about how the financial system should work, and because powerful states (the US) exerted pressure on more reluctant countries.

Other authors (e.g., Murphy 2004; Simmons 2001; Murphy and Oye 1998; Oatley and Nabors 1998; Genschel and Plümper 1997) concentrate primarily on explaining the establishment and diffusion of the Basle standards on the basis of strategic interactions among G-10 countries. For example, Oatley and Nabors (1998) argue that domestic politics rather than international market failure were the principal motivation of US policymakers to push for the Basle Accord. The Basle Accord, in their view, did not aim at joint gains for the participating countries (as assumed by the public goods argument) but at redistributing income from Japanese to US commercial banks. Similarly, Kane (1990) claims that the Basle Accord is a cartel-like agreement among G-10 and EU bank regulators designed to limit regulatory competition. He also claims that non-Japanese regulators tried to use the Basle Accord to roll back Japanese penetration of European and American financial markets.

Only recently, because of more systematic collection and publication of data, have analysts become aware that many banks in OECD countries have, throughout the 1990s, over-complied with regulatory requirements, and that there is strong heterogeneity in capital to asset ratios within and across countries (see Figure 1). These patterns create problems for existing theories. If the Basle regulations were primarily an instrument to level the international playing field in banking, as many authors claim (e.g., Oatley and Nabors 1998), we should expect more convergence of capital to asset ratio around the minimum Basle standards (total capital to asset ratio $=8 \%$, and Tier $1=4 \%$ ) and thus less over-compliance than we actually do. ${ }^{6}$ Similarly, the observation that several national banking sectors (on average) over-complied already before the Basle standards entered into effect is prima facie evidence against the theory that the Basle Accord constituted a case of redistributive international cooperation in which the United States forced the Basle standards upon other countries.

\footnotetext{
6 Even if we consider that some national regulators may require some banks to hold a higher CAR than required by the Basle Accord and that there are measurement problems, the observed variance and substantial over-compliance shown in Figure 1 is, prima facie, not consistent with the level playing field argument. Indeed, a 1999 Bank for International Settlements (BIS) study notes that the existing literature does not provide systematic answers to the question of why capital to asset ratios continue to vary strongly across countries and banks, and what role market discipline, regulation, and other factors play in this regard.
} 
Figure 1: Average Capital-Asset-Ratios of Banking Sectors in Selected G-10 Countries

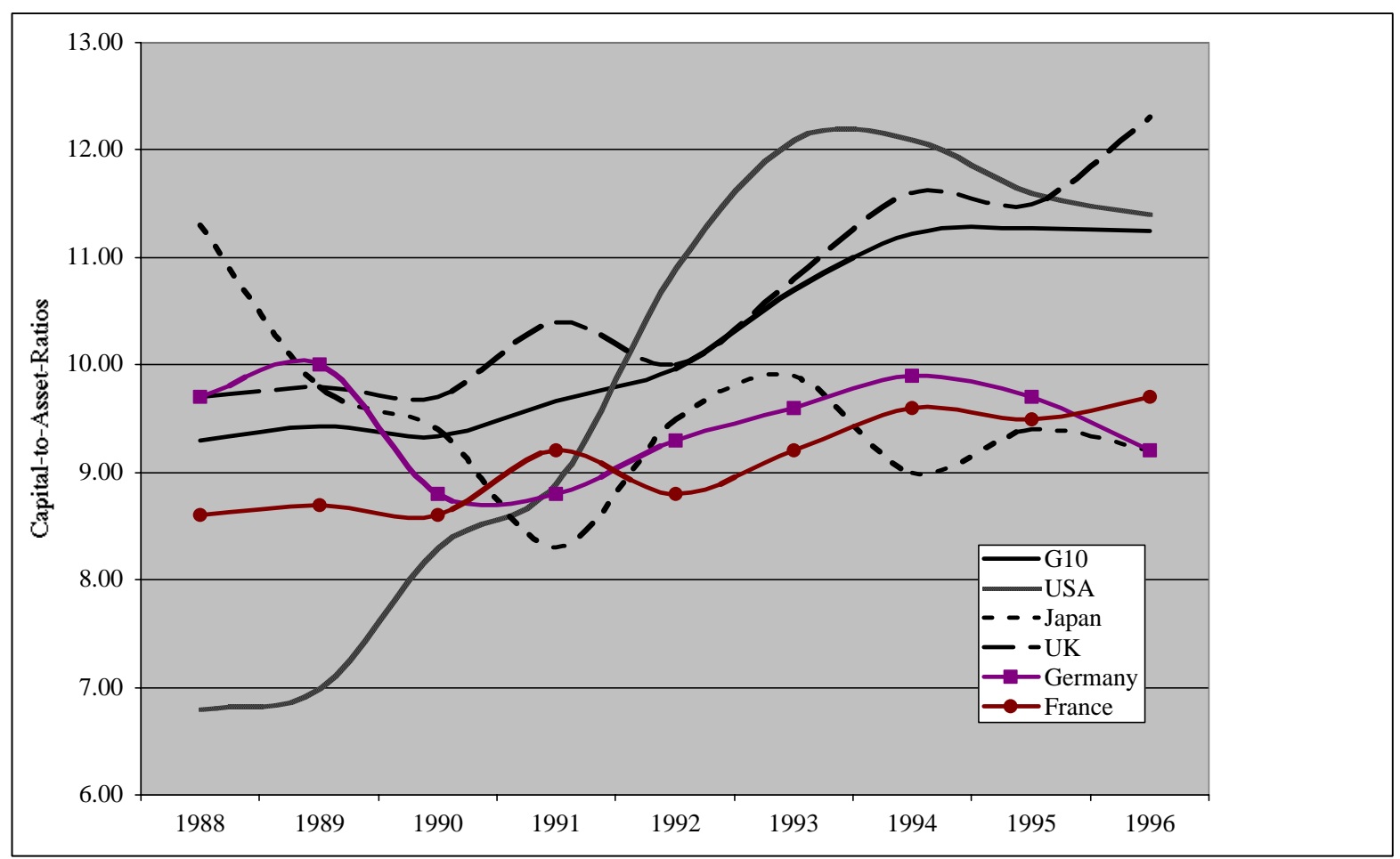

Source: Dutch National Bank. The CAR indicator in this figure is defined as the total (Tier 1+2) BIS riskweighted capital-asset ratio.

We think that these inconsistencies between empirical data and extant theoretical arguments are due to the fact that these theories seem to ignore the interconnectedness between the two most important determinants of capitalization decisions of banks: regulatory policy and market forces. Our view is that competition before the Basle Accord was already motivating some banks to choose high capital-asset ratios. International competition at that stage was, however, hindered by the lack of common international standards that could facilitate judgment of bank quality. The inability of economic actors to differentiate among banks based on quality meant that poorly capitalized banks were able to free-ride on stronger banks. Such behavior had negative effects on banks holding higher levels of capital (negative externalities). It also contributed to an increase in systemic risk in the world economy. International regulation thus became necessary not so much because the average bank was undercapitalized, but rather as a means for increasing international competition (which, of course, would favor efficient banks, such as those located in the US and the UK). The Basle standards unleashed capitalization-enhancing competitive forces among banks by creating more transparency and becoming a focal point for financial 
markets. Rating agencies, such as FitchIBCS, Standard \& Poor's, and Moody's, attempting to cope with the growing complexity of global financial markets and minimize their information costs, increasingly used capital-asset ratios, as defined by the Basle Accord, as a simple benchmark to assess the quality of banks. The Basle standards generated data on capital-asset ratios that was, in most G-10 countries, unavailable before. And by harmonizing reporting requirements, the Basle standards made financial intermediaries comparable within and across countries, opening them up to the scrutiny of international investors.

We are not the first ones to make an argument along these lines. Other authors (Murphy, 2004; Murphy and Oye, 1998; Genschel and Plümper 1997; Porter, 1993) have noted before that market pressure may help explain the rapid acceptance and diffusion of the Basle capital adequacy standards. These authors have argued that the Basle standards increased transparency, allowing financial markets to punish poorly capitalized banks and/or entire national banking systems faster and harder, and to reward banks and banking systems with higher capital-asset ratios. Nevertheless, these authors have stopped short of specifying the market argument in more detail and buttressing it with empirical work.

There are a few studies of the role of market pressure. Jacques and Nigro (1997), in an analysis of around 2'500 US commercial banks 1990-91, observe that banks with capital-asset ratios higher than the required minimum - banks presumably less exposed to regulatory pressure - responded to the new Basle standards by increasing their capital-asset ratios and reducing portfolio risk more than banks with capital-asset ratios closer or below the regulatory minimum. Rime (2000) shows that Swiss banks maintaining large capital buffers beyond the regulatory minimum may have been driven by market incentives such as access to capital markets and the cost of raising capital. In contrast to Jacques and Nigro (1997), Rime finds that banks closer to or below the regulatory minimum increased their capitalasset ratios more than banks clearly above the minimum standard. In virtually all studies of this type, capital adjustment rates are taken as a sign of regulatory pressure, without distinguishing whether pressure emanates from regulators or from markets.

In a recent paper, <authors> (2003) argue that competition may force banks to select levels of capital that significantly exceed officially imposed minimum requirements (but may still fall short of socially optimal levels). If depositors care more about idiosyncratic bank risk (because they hold unsecured loans), then the capital-asset ratio can be a powerful 
instrument for improving relative bank attractiveness and gaining a cost advantage over one's rivals. Competition among banks drives capital-asset ratios upward, perhaps to levels that exceed both the minimum requirement and the socially optimal level, removing the need for government mandated minimum capital requirements. This situation is more likely to emerge when banks play a unique role in the financial system in the sense that other financial instruments cannot easily replicate the properties of their deposits.

To the extent that competitive forces in individual countries support high capitalization, and the same pattern is present in different countries, regulatory convergence (for instance, adoption of the Basle Accord) does not give rise to significant conflicts among states and will thus emerge more easily. Moreover, regulatory convergence may occur even when some countries' banking sectors are less exposed to competitive forces (say, due to cartelization or oligopolies), as long as there exist global market forces that influence bank behavior in individual country markets (for instance, when some of the domestic banks operate internationally). In other words, globalization may promote regulatory convergence by weakening sources of cross-country heterogeneity.

<Authors> (2003) test their theory using 15'000 US banks in the 1990s. They find that the effect of bank capital on borrowing costs in the US has been substantial. In particular, an increase in the average bank's tier 1 capital by 10\% lowers this bank's borrowing costs by $3.5 \%$ to $6 \%$, depending on the bank's level of capital (the effect is larger at lower levels of capitalization).

In summary: Traditional explanations of capital adequacy regulation suffer from inconsistencies and gaps. In particular, they cannot systematically account for heterogeneity and over-compliance and, more generally, variation in the capital to asset ratio across banks, countries, and time. Recent political science work contains suggestions that market pressure may have played a role in the implementation of regulation. But this work is limited largely to the US banking sector. Moreover, it does not systematically assess the individual and combined effects of markets, regulation, macro-economic conditions, and bank characteristics on bank behavior. We seek to fill this gap by using data on banks and banking regulation from a relatively large number of countries. 


\section{Empirical Analysis}

In this section we investigate the empirical determinants of capital-asset ratios across banks in OECD countries.

\section{Variables}

There are many candidate variables for explaining heterogeneity and over-compliance in bank capital-asset ratios. We organize the empirical analysis around four categories of variables and use representative variables for each category as dictated by theory and data availability. In particular, the observed level of bank capitalization is assumed to depend on variables belonging to four categories: market forces (competition), regulatory measures and other types of government intervention, macro-economic variables, and bank characteristics.

\section{a. Market forces (competition)}

As mentioned above, <authors> (2003) developed a model in which banks choose to hold high levels of capital in order to improve depositors' perceptions of banks' riskiness and hence enable banks to attract funds (deposits) more cheaply. Their empirical analysis produces strong support for this claim. Consequently, we use two variables to capture market pressure on banks' capitalization choices.

Government-owned banks (government) (all variables are defined in the Appendix). We expect public enterprises to be less sensitive to competition because many of them benefit from government support in various forms (e.g., state guarantees, bailouts, regulatory exemptions). Hence the higher the share of state owned banks in a given national banking system, the lower will be the effect of market pressure and hence the lower the capital-asset ratio.

The second variable is a banking concentration index (concentration). We expect that the more oligopolistic the banking sector in a given country is (the smaller the number of banks 
dominating the respective market) the weaker competition will be in that market, and hence the lower will be the incentive of banks to hold high levels of capital as a means of improving their attractiveness to depositors.

Bank ratings are another variable that may enhance competition and sound banking practices. We have not included this variable in the analysis for two reasons. The first and main reason is data availability. Only a small subset of the banks in our sample is rated (less than $25 \%$ ). Restricting attention to this subset would lead to a serious loss of information, especially at the cross country level and would undermine our ability to make cross country comparisons (which is the key focus of the analysis). The second reason is that the capitalization variable is itself used to produce the ratings, so inclusion of ratings as an explanatory variable would lead to a simultaneity problem. ${ }^{7}$

\section{b. Regulatory measures and other types of government intervention}

The effect of regulation on bank capitalization tends to be regulation-specific. Some regulatory measures, such as official minimum capital requirements, have a direct and positive effect on capital-asset ratios. Thus we include overall capital stringency (stringency) to account for the extent to which there are explicit regulatory requirements regarding the amount of capital banks must hold. Note that the Basle Accord sets international floor standards, but individual countries may (and actually have) established national regulations that differ from international standards - some of these standards are, at varying rates, stricter than the Basle standards.

Other types of government intervention may have more indirect and ambiguous effects. Consider, for instance, the power of regulators to take prompt action to restructure or declare insolvent a troubled bank. On the one hand, more power to take such strong action forces bank managers to select high levels of capital in order to save their jobs. On the other hand, it increases the faith placed by depositors in the ability of policymakers to

\footnotetext{
7 Matten (1996) examines the relationship between capital-asset ratios and bank ratings. He does not find a relationship between Moody's ratings and Tier 1 capital, but finds a relationship between Tier 1 capital and Standard \& Poor's ratings. Methodologically, Matten's results are problematic because his test is based on an unspecified sample of international banks in unspecified years.
} 
ascertain solvency and liquidity in a given banking system. This serves as a positive externality for the banking system and reduces the need of the banking sector to use high capitalization as a means of establishing its trustworthiness and attracting funds (deposits) at the expense of non-bank destinations.

We use two variables to assess such effects: Promptness of action (prompt) and declaring insolvency power (declare) in case of bank trouble. The former variable is constructed with reference to the ability of bank supervisors to take prompt corrective action. It measures whether a law establishes pre-determined levels of bank solvency deterioration that mandate automatic enforcement action. With prompt corrective action provisions regulators do not have the option of refraining from exercising their regulatory right to put an insolvent bank out of business (Mishkin, 1997). The latter variable is constructed with reference to the ability of bank supervisors to declare a troubled bank insolvent. For both variables we expect ambiguous results: for theoretical reasons stated above, both variables may encourage or discourage higher bank capitalization.

While there are some additional variables describing the strictness and effectiveness of regulatory frameworks, we had to restrict attention to the two variables just listed in order to avoid collinearity problems (the regulatory variables tend to be highly correlated), and also in order to save degrees of freedom along the cross country dimension (recall that we have a limited number of countries and there is no regulatory variation within a single country).

Deposit insurance (insurance) is another, important, type of government intervention. We also expect this variable to have an ambiguous effect on bank capitalization. On the one hand, deposit insurance creates a standard moral hazard problem (i.e., incentives of banks and/or depositors to accept risks they would otherwise not accept). It thus motivates banks to rely less on capitalization as a means of signaling their trustworthiness, because depositors are less concerned about bank risks when their assets are insured. On the other hand, deposit insurance means that the insurers (private or the government) have a lot at stake when banks take excessive risks. Hence they have a stronger incentive to minimize risk taking by banks by pressuring them (primarily through high capital adequacy standards and their enforcement) to hold more capital. High bank capitalization may therefore represent the implicit insurance sought after by the institutions that insure deposits. 


\section{c. Economic conditions}

We expect ambiguous effects of macro-economic conditions on bank capitalization for reasons discussed by <authors> $(2002,2004)$. In periods of weak macro-economic performance banks have an incentive to raise their capitalization to avoid trouble with both the authorities and the depositors. But, at the same time, they find it harder to raise capital during such times (Mishkin, 1997). Similarly, policymakers face a conflict between higher systemic risk (when bank capitalization is low) and a credit crunch (when they force banks to hold more capital). However, <authors> $(2002,2004)$ find that bank capital tends to move counter-cyclically: that is, banks tend to increase capital during economic downturns. We use real GDP growth (ggdp) to capture general economic conditions.

\section{d. Bank characteristics}

The variables described above are used to account for differences in cross-country (national) capital to asset ratio. As noted above, we also need to account for the substantial heterogeneity observed across banks within the same country. We thus include in the analysis an individual bank characteristic, namely bank assets (assets). This variable, which captures the size of the banks, is expected to have an ambiguous effect on bank capitalization. On the one hand, a negative effect arises from the definition of this variable, namely from the fact that assets appear on the denominator of the capital-asset ratio variable, albeit in modified form (risk-weighed assets). Moreover, big banks are more likely to get bailed out when they run into trouble because policy-makers tend to be more worried about systemic effects should big banks fail (the "too big to fail" effect). Big banks have an incentive to hold less capital than small banks because they are less likely to be punished by investors (depositors) for doing so. On the other hand, large banks are more likely to be internationally active and may thus face greater competition, something that may require them to hold more capital in order to enhance their reputation.

There are additional bank specific variables that could be used in the analysis in order to improve our ability to capture cross bank variation in capitalization. We have not included bank employment because it is just another measure of size. As it is highly positively correlated with assets its inclusion would not add much. We have also decided against using 
other variables that are important for capitalization decisions, such as the amount of subordinate debt (a variable that affects bank financing decisions by private investors) because of many missing observations. Their inclusion might enhance the ability of the model to account for individual bank heterogeneity but this would come at the expense of lower cross country variation as this information is not available for many countries (for instance, we have data on subordinate debt for only 239 banks).

Our dependent variable is the Tier 1 capital-asset ratio (CAR). Because of differences across countries in the measurement of Tier 2 capital (as mentioned above), meaningful cross-country comparisons of the capital holdings of banks can be made only on the basis of Tier 1 capital. However, we also ran the empirical analysis with total capital asset-ratios $($ TCAR $=$ Tier $1+$ Tier 2 capital-asset ratios) and the results reported below did not differ across these two ratios.

\section{Results}

Combining the market, regulation, economic, and individual bank characteristic variables hypothesized to affect bank capital-asset ratios we obtain the following model:

$$
\begin{aligned}
\text { CAR }_{\mathrm{ik}}=\quad & \mathrm{C}+\beta_{1} \text { government }_{\mathrm{k}}+\beta_{2} \text { concentration }_{\mathrm{k}}+\beta_{3} \text { stringency }_{\mathrm{k}}+\beta_{4} \text { prompt }_{\mathrm{k}} \\
& +\beta_{5} \text { declare }_{\mathrm{k}}+ \\
& \beta_{6} \text { insurance }_{\mathrm{k}}+\beta_{7 \text { ggdp }_{\mathrm{k}}}+\beta_{8} \text { assets }_{\mathrm{ik}}+\mathrm{e}
\end{aligned}
$$

where

$$
\begin{array}{ll}
\mathrm{CAR}_{\mathrm{ik}}= & \text { Tier } 1 \text { capital of bank } \mathrm{i} \text { in country } \mathrm{k} \\
\mathrm{C}= & \text { intercept } \\
\text { government }_{\mathrm{k}}=\quad & \begin{array}{l}
\text { fraction of the banking system's assets that are } 50 \text { percent or more } \\
\text { government owned in country } \mathrm{k}
\end{array} \\
\text { concentration }_{\mathrm{k}}=\quad & \text { fraction of deposits held by the five largest banks in country } \mathrm{k}
\end{array}
$$




$$
\begin{aligned}
& \text { stringency }_{\mathrm{k}}=\quad \text { (ranging from } 0 \text { to } 6 \text { ) existence of explicit regulatory requirements in } \\
& \text { ountry k regarding the amount of capital a bank must hold } \\
& \text { prompt }_{\mathrm{k}}=\quad \text { (ranging from } 0 \text { to 6) pre-determined levels of bank solvency } \\
& \text { deterioration established by law in country } \mathrm{k} \text { that mandate automatic } \\
& \text { enforcement action } \\
& \text { declare }_{\mathrm{k}}=\quad \text { (ranging from } 0 \text { to } 2 \text { ) extent to which the supervisory authorities in } \\
& \text { country } \mathrm{k} \text { have the power to declare a deeply trouble bank insolvent } \\
& \text { insurance }_{\mathrm{k}}=\quad \text { (dummy variable) presence of explicit deposit insurance in country } \mathrm{k} \\
& \operatorname{ggd} \mathrm{p}_{\mathrm{k}}=\quad \text { growth of the real gross domestic product of country } \mathrm{k} \\
& \text { ssets }_{\mathrm{ik}}=\quad \text { total bank assets of bank i located in country } \mathrm{k} \\
& \mathrm{e}=\quad \text { error term }
\end{aligned}
$$

The analysis is done on 1267 banks from 29 OECD countries for the year 1999. Our dataset includes the total number of observations for bank capital-asset ratios that is available from the Bankscope data base. Bankscope covers mostly large banks. In view of the objectives of this paper, this coverage is advantageous because large banks are more likely to be subject to international competition and regulation. While Bankscope offers, albeit short, time series for bank variables, we were forced to use a single period cross sectional panel rather than pooled data because the regulatory variables for the cross section of countries are only available for a single year (1999).

Data on regulation was taken from the World Bank database on the regulation and supervision of banks (Barth et al (2001)). Data on macro-economic conditions was taken from the International Monetary Fund's database on International Financial Statistics, and bank size was obtained from Bankscope. All variables and their sources are described in the appendix.

Table 1 shows summary statistics for Tier 1 capital (the dependent variable in the analysis) in selected countries and the OECD as a whole. It demonstrates strong heterogeneity (see standard deviations) in capital-asset ratios across banks and, on average, massive over-compliance with the Basle standards (see the means). 
Table 1: Summary Statistics (Banks, Countries)

Variable: Tier 1 capital-asset ratios for selected countries

\begin{tabular}{|c|c|c|c|c|c|}
\hline Country & Obs. & Mean & Std. Dev. & Min. & Max. \\
\hline US & 600 & 15.28342 & 18.39401 & 6.4 & 340.6 \\
\hline UK & 24 & 17.19708 & 20.21972 & 6.4 & 103 \\
\hline ITA & 294 & 17.12891 & 10.53241 & 1.08 & 79.6 \\
\hline FRA & 69 & 17.56217 & 14.45556 & 7 & 102.1 \\
\hline OECD & 1267 & 14.97942 & 15.25388 & 1.08 & 340.6 \\
\hline
\end{tabular}

Note: Austria, Belgium and Germany are the countries with a national average below 8\%.

Variation in the Tier 1 capital-asset ratio across countries is quite small (Table 2 shows summary statistics for country averages), especially in comparison to the within country variation. That is, the objects of international banking regulation (the banks) exhibit great harmonization across countries. We will claim below that this private harmonization may have made the adoption of the Basle Accord much easier.

Table 2: Summary Statistics (Countries)

Variable: Tier 1 capital-asset ratios for OECD countries (country averages)

\begin{tabular}{|l|l|l|l|l|l|}
\hline Variable & Obs. & Mean & Std. Dev. & Min. & Max. \\
\hline tier1 & 29 & 14.97942 & 2.501769 & 6.583333 & 24.88 \\
\hline sd_tier1 & 28 & 13.96527 & 5.800979 & .4843898 & 26.14655 \\
\hline
\end{tabular}

Note: The sd_tier1 variable represents the standard deviation of tier 1 capital-asset ratios within individual countries. 
Table 3 reports correlations for the independent variables. As can be seen, multicollinearity is not a problem.

Table 3: Correlations across countries

\begin{tabular}{|l|l|l|l|l|l|l|l|l|l|}
\hline & tier1 & govt & conce & string & prompt & declare & insur & ggdp & asst \\
\hline tier1 & 1.00 & & & & & & & & \\
\hline govt & 0.15 & 1.00 & & & & & & & \\
\hline concentr & -0.06 & -0.14 & 1.00 & & & & & & \\
\hline string & -0.29 & -0.16 & -0.20 & 1.00 & & & & & \\
\hline prompt & -0.29 & -0.20 & -0.35 & 0.06 & 1.00 & & & & \\
\hline declare & 0.05 & 0.56 & -0.07 & -0.21 & 0.26 & 1.00 & & & \\
\hline insuranc & 0.26 & 0.30 & -0.29 & -0.26 & 0.21 & 0.27 & 1.00 & & \\
\hline ggdp & -0.52 & -0.15 & 0.08 & 0.36 & 0.00 & -0.13 & -0.14 & 1.00 & \\
\hline assets99 & -0.41 & 0.06 & -0.28 & 0.12 & 0.06 & -0.08 & 0.15 & -0.15 & 1.00 \\
\hline
\end{tabular}


Table 4 contains the main results of the analysis. The analysis uses Least Squares with the White correction for heteroskedasticity.

Table 4: Determinants of Tier 1 Capital-Asset Ratios (tier1)

Regression with robust standard errors

\begin{tabular}{|l|l|l|l|l|}
\hline & Coef. & Std. Err. & $\mathrm{t}$ & $\mathrm{P}>|\mathrm{t}|$ \\
\hline government & -.1577151 & .0389169 & -4.053 & 0.000 \\
\hline concentration & -.0726444 & .0160258 & -4.533 & 0.000 \\
\hline stringency & .0606086 & .3036992 & 0.200 & 0.842 \\
\hline prompt & -1.61012 & .3760588 & -4.282 & 0.000 \\
\hline declare & 2.15981 & .7754335 & 2.785 & 0.005 \\
\hline insurance & 4.308177 & 1.110295 & 3.880 & 0.000 \\
\hline ggdp & -.5850071 & .2064759 & -2.833 & 0.005 \\
\hline assets & $-2.15 \mathrm{e}-08$ & $2.53 \mathrm{e}-09$ & -8.485 & 0.000 \\
\hline cons & 17.30989 & 2.210124 & 7.832 & 0.000 \\
\hline
\end{tabular}

Number of obs. $=1184$

R-squared $=0.0773$

$\mathrm{F}(8,1175)=25.09$

Prob $>\mathrm{F}=0.0000$

Banks in countries with a relatively large state-owned banking sector (government) tend to hold less capital. Similarly, countries in which a small number of banks dominate (indicating higher market concentration and a lower level of bank competition, concentration) exhibit lower capitalization too. Hence the effect of the market pressure variables on bank capital is positive. The effect of general economic conditions (real GDP growth, ggdp) suggests a counter-cyclical pattern, a finding that is in line with results of <authors> (2002, 2004). When economic growth is slow bank capitalization is higher, and vice versa.

The signs of the coefficients for the regulatory variables depend on the measure used. On the one hand, the sign of declare (declaring insolvency power) is positive. Giving regulators a big stick seems to motivate banks to try and stay out of trouble. On the other 
hand, the effect of the prompt variable (promptness) is negative. A possible explanation for this negative effect may have to do with the perceptions of bank lenders about the safety of their loans. If the lenders know that the regulators will take prompt action to keep banks from misbehaving, they may consider bank loans as a safer asset and will require a smaller direct assurance of safety by the banks (in the form of a higher capitalization ratio).

Finally, deposit insurance has a positive effect on bank capitalization. This suggests that the moral hazard problem may not be as serious as frequently proclaimed by the critics of deposit insurance. Countries with deposit insurance may indeed be leaning harder on banks to maintain sufficient capital so as to save taxpayers or insurance firms from the negative consequences of bank failures. This argument receives support from the finding in Table 3 that the variables prompt and declare are strongly positively correlated with insurance.

The fact that the $\mathrm{R}^{2}$ (explained variance) is low is not troubling given the focus of this paper on regulation and market forces, both of which are country rather than bank specific. The low $\mathrm{R}^{2}$ in our case simply reflects the fact that there is much variation within countries and only one source of within-country heterogeneity that is included in the regressions, namely bank size (assets). The bank size variable leaves much of within-country variation, which is the dominant source of variation in the sample unexplained (see Table 2). Nonetheless, while the model cannot explain much of the within country heterogeneity, it does a good job (in terms of explanatory power) in explaining cross country heterogeneity.

We have also carried out a robustness analysis by using robust regression techniques (which aim at minimizing the problems associated with outliers). The results are identical to those reported in Table 4.

It is worthwhile to investigate whether the external benefits claimed for the promptness variable are felt uniformly across banks, independent of their health (capitalization). Banks with low capitalization face a higher likelihood of regulatory intervention. For such banks the more imminent the intervention, the more likely it is that they would take corrective action in the form of higher capitalization. To examine this possibility we regressed the capital-asset ratio on promptness for both the entire sample of banks and the subsets of banks with low capitalization. We used a threshold value of 10\% (Tier 1 capital-asset ratio) to separate banks with low from banks with high capitalization. However, the results are similar when using 
$8 \%$ instead. Tables 5 and 6 suggest that the effects are not uniform. Regulatory power does make a difference for low capitalized banks (Table 5). But it has no effect on capitalization of the average bank (Table 6$)$.

Table 5: Regulatory stringency and bank capitalization: Low capitalization banks (tier1<10)

Regression with robust standard errors

\begin{tabular}{|l|l|l|l|l|}
\hline & Coef. & Std. Err. & $\mathrm{t}$ & $\mathrm{P}>|\mathrm{t}|$ \\
\hline prompt & .1908527 & .0359002 & 5.316 & 0.000 \\
\hline cons & 7.450952 & .1475259 & 50.506 & 0.000 \\
\hline
\end{tabular}

Number of obs. $=437$

R-squared $=0.0714$

$\mathrm{F}(1,435)=28.26$

Prob $>\mathrm{F}=0.0000$

Table 6: Regulatory stringency and bank capitalization: All banks

Regression with robust standard errors

\begin{tabular}{|l|l|l|l|l|}
\hline Tier1 & Coef. & Std. Err. & $\mathrm{t}$ & $\mathrm{P}>|\mathrm{t}|$ \\
\hline prompt & -.2351052 & .2173943 & -1.081 & 0.280 \\
\hline cons & 15.85427 & .6942197 & 22.838 & 0.000 \\
\hline
\end{tabular}

Number of obs. $=1238$

R-squared $=0.0009$

$\mathrm{F}(1,1236)=1.17$

Prob $>\mathrm{F}=0.2797$

The indicator capturing overall stringency of prudential regulation (stringency) has no significant effect on bank capitalization. Since this indicator captures primarily formal regulation, its insignificance may reflect a situation where informal rules and their 
enforcement matter more. Alternatively, it may suggest that regulation is not the main driving force of bank capitalization.

\section{Conclusions}

The research presented in this paper has been driven by two sets of motivations. The first is somewhat narrow. We try to make sense of the empirical observation that banks choose to systematically hold more capital than required by domestic and international regulation (the over-compliance phenomenon). This observation cannot be accounted for by extant theories that emphasize political and economic interests, knowledge, ideas, and power as the main driving forces behind the initiation and widespread adoption of international banking regulation, notably, the Basle Accord. Our findings suggest an alternative explanation that emphasizes the role of market forces in determining individual bank capitalization decisions. However, the fact that banks, on average, over-comply significantly does not mean that regulatory requirements are misguided or even redundant. We conclude from the above analysis that regulation, such as the Basle Accord, may be indirectly credited for over-compliance by having defined a framework that increased transparency and comparability of banks within and across countries, thus encouraging competition and higher bank quality.

The second motivation is more fundamental. We try to understand what lessons the observed interaction of regulatory and market processes in the banking industry holds for the relation between regulatory policy and markets in other areas, and for the prospects for international regulatory convergence. Both issues are subjects of intense debate in the globalization and varieties of capitalism literature. We conclude that to the extent regulation increases transparency and comparability across firms and national borders regulation and markets can reinforce each other. A relatively modest regulatory intervention can have amplified effects with the help of market processes. The existence of market forces can also make the implementation of regulation less controversial and thus easier. Under these circumstances, international regulatory convergence need not be the outcome of top-down policies (harmonization) led by dominant countries, as suggested by hegemonic stability theory. It may very well evolve in cooperative ways motivated by desires to help domestic 
firms maintain or increase international competitiveness. We have pointed to corporate governance, accounting, and environmental standards as obvious areas of application for the lessons learned from banking regulation.

Our finding that market forces have played an important role in facilitating the establishment and effective implementation of international banking regulation can also be understood within the typology of effects of international institutions on member state behavior, as suggested by Botcheva and Martin (2001). According to Botcheva and Martin, regulatory divergence effects are “...likely to be observed only when externalities are minimal, enforcement mechanisms are weak and states exhibit significant variation in the organization and power of groups..."

In our assessment, the internationalization (globalization) of financial markets means that none of these conditions for regulatory divergence is met for the international banking system. First, the existence of international banks, that is, banks that draw funds and offer loans and other services in more than one national market, implies significant international externalities. Undercapitalized banks contribute to systemic risk in all countries they operate in. Second, enforcement mechanisms are strengthened by global financial market integration as the reach of national regulators expands. It is well known that banks - or, in general, corporations - that do not wish to be shut out of lucrative markets, such as the EU or the United States, must conform to the standards and requirements set by public authorities and demanded by investors in these countries. Third, global market integration tends to reduce cross-national asymmetries in economic structure (for instance, in the degree of competition within national boundaries) and in corporate behavior, thus eliminating an important obstacle to international regulatory harmonization. 


\section{Bibliography}

$<$ Authors $>2002$.

$<$ Authors $>2003$.

$<$ Authors $>2004$.

Basle Committee on Banking Supervision. 1999. Capital Requirements and Bank Behavior: The Impact of the Basle Accord. Working Paper 1. Basel, Switzerland: Monetary and Economic Department, Bank of International Settlements.

Barth, James R., Gerard Caprio, Jr. and Ross Levine. 2001. The Regulation and Supervision of Banks around the World. World Bank:

http://www.worldbank.org/research/projects/bank_regulation.htm

Berger, Allen N., Richard J. Herring, and Giorgio P. Szego. 1995. The Role of Capital in

Financial Institutions. Journal of Banking and Finance 19: 393-430.

Berger, Suzanne, and Ronald Dore, eds. 1996. National Diversity and Global Capitalism. Ithaca, Cornell UP.

Berger, Suzanne. 2000. Globalization and Politics. Annual Review of Political Science 3:

43-62.

Botcheva, Liliana and Lisa L. Martin. 2001. Institutional Effects on State Behavior:

Convergence and Divergence. International Studies Quarterly 45 (1): 1-26.

Cerny, Philip. 1990. The Changing Architecture of Politics: Structure, Agency, and the

Future of the State. Sage Publications.

Cerny, Philip. 2005. Power, Markets and Authority: The Development of Multi-Level Governance in International Finance. In Andrew Baker, Alan Hudson and Richard Woodward, eds., Money, Finance and Multi-Level Governance. (Routledge, forthcoming)

Genschel, Philipp and Thomas Plümper. 1997. Regulatory Competition and International Cooperation. Journal of European Public Policy 4 (4): 626-642.

Gilpin, Robert. 2001. Global Political Economy: Understanding the International Economic Order. Princeton, NJ: Princeton University Press. 
Hall, Peter A., and David Soskice. 2001. Varieties of Capitalism: The Institutional Foundations of Comparative Advantage. Oxford: Oxford University Press.

Jacques, Kevin and Peter Nigro. 1997. Risk-Based Capital, Portfolio Risk, and Bank Capital: A Simultaneous Equations Approach. Journal of Economics and Business 49: 533-547.

Jordana, Jacint, and David Levi-Faur, eds. 2004. The Politics of Regulation: Institutions and Regulatory Reforms for the Age of Governance. Cheltenham: Edward Elgar.

Kane, E.J. 1990. Incentive Conflict in the International Risk-based Capital Agreement. The Federal Reserve Bank of Chicago, Economic Perspectives, May/June, 33-36.

Kapstein, Ethan Barnaby. 1989. Resolving the Regulator's Dilemma: International Coordination of Banking Regulations. International Organization 43 (2): 323-47.

Kapstein, Ethan Barnaby. 1992. Between Power and Purpose: Central Bankers and the Politics of Regulatory Convergence," International Organization 46 (1): 265-287.

Kapstein, Ethan Barnaby. 1994. Governing the Global Economy. International Finance and the State. Cambridge MA: Harvard University Press.

Kitschelt, Herbert, Peter Lange, Gary Marks and John D. Stephens (eds).1999. Continuity and Change in Contemporary Capitalism. Cambridge: Cambridge University Press.

Majone, Giandomenico. 1996. Regulating Europe. London: Routledge.

Matten, Chris. 1996. Managing Bank Capital: Capital Allocation and Performance

Measurement. Chichester, England: John Wiley \& Sons.

Mishkin, Frederic S. 1997. The Economics of Money, Banking, and Financial Markets. AddisonWesley. $5^{\text {th }}$ Edition.

Murphy, Dale D. 2004. The Structure of Regulatory Competition: Corporations and Public Policies in a Global Economy. Oxford: Oxford University Press.

Murphy, Dale D. and Kenneth A. Oye. 1998. Comparative (Regulatory) Advantage: FirmState Relations in the Global Economy. Paper Presented at the Annual Meeting of the International Studies Association, March 18, Minneapolis, MN.

Oatley, Thomas and Robert Nabors. 1998. Redistribute Cooperation: Market Failure, Wealth Transfers, and the Basle Accord. International Organization 52 (1): 35-54.

Porter, Tony. 1993. States, Markets and Regimes in Global Finance. New York: St Martin's Press.

Rime, Bertrand. 2000. Capital Requirements and Bank Behavior: Empirical Evidence for Switzerland. Unpublished manuscript, Swiss National Bank, Zurich, Switzerland. 
Santos, Joao A.C. 2000. Bank Capital Regulation in Contemporary Banking Theory: A Review of the Literature. Working Paper 90. Basel, Switzerland: Monetary and Economic Department, Bank of International Settlements.

Simmons, Beth A. 2001. The International Politics of Harmonization: The Case of Capital Market Regulation. International Organization 55 (3): 589-620.

Strange, Susan. 1998. Mad Money. Manchester: Manchester University Press.

Thatcher, Marc. 2004. Varieties of Capitalism in an Internationalized World: Domestic Institutional Change in European Telecommunications. Comparative Political Studies 37 (7): 751-780.

Underhill, Geoffrey R.D. 1997. The New World Order in International Finance. New York: St. Martin's Press.

Vogel, Steven K. 1998. Freer Markets, More Rules: Regulatory Reform in Advanced Industrial Countries. Ithaca NY: Cornell University Press.

Wagster, J.D. 1996. Impact of the 1988 Basle Accord on International Banks. Journal of Finance 51: 1321-1324. 


\section{Appendix: Variable definitions and data sources}

The analysis is done on 1267 banks from 29 OECD economies for the year 1999. Turkey has only one bank included. Excluding Turkey from the sample does not affect the results reported above.

Tier 1 ratio: this measure of capital adequacy includes shareholder funds plus perpetual non cumulative preference shares as a percentage of risk-weighted assets and off balance sheet risks measured under the Basle rules. These rules hold that the Tier 1 ratio should be at least 4 percent. Source: Bankscope. Bankscope is a database on banking produced by Fitch IBCA and Bureau Van Dijk. (http://bankscope.bvdep.com)

Government-owned banks: the fraction of the banking system's assets that are 50 percent or more government owned.

Source: World Bank, Bank Regulation and Supervision dataset. The data and description file can be found at the World Bank's website for financial research, http://www.worldbank.org/research/projects/bank_regulation.htm

Bank Concentration: the fraction of deposits held by the five largest banks in a given banking system.

Source: World Bank, Bank Regulation and Supervision dataset.

Overall capital stringency: whether there are explicit regulatory requirements regarding the amount of capital that a bank must have relative to various guidelines. Several guidelines are included in order to determine the degree to which the leverage potential for capital is limited, such as whether the minimum required capital-asset ratio conforms to the Basle guidelines and whether the minimum ratio varies with market risk. The overall capital stringency variable ranges in value from 0 to 6 , with higher values indicating greater stringency.

Source: World Bank, Bank Regulation and Supervision dataset.

Promptness (Prompt corrective action): whether a law establishes pre-determined levels of bank solvency deterioration that invoke automatic enforcement actions such as intervention. This variable also includes supervisory elements such as whether the supervisory authorities can force a bank to change its internal organizational structure, order 
a bank's directors/managers to provide provisions to cover actual or potential losses, and suspend the directors' decision to distribute dividends, bonuses and management fees. The promptness variable ranges from 0 to 6 , with a higher value indicating more promptness in responding to problems.

Source: World Bank, Bank Regulation and Supervision dataset.

Declaring insolvency power: whether supervisory authorities have the power to declare a deeply troubled bank insolvent. In particular it refers to whether the supervisory authorities can supersede shareholder rights and declare a bank insolvent and also suspend some or all ownership rights of a problem bank. This variable ranges in value from 0 to 2 , with a higher value indicating more power.

Source: World Bank, Bank Regulation and Supervision dataset.

Deposit insurance: whether there is an explicit deposit insurance scheme.

Source: World Bank, Bank Regulation and Supervision dataset.

GDP growth: real gross domestic product (GDP) growth.

Source: International Financial Statistics, The International Monetary Fund.

Assets: total bank assets in thousands of US dollars.

Source: Bankscope. 


\section{About the Authors}

Thomas Bernauer is Full Professor of Political Science (International Relations) at the Swiss Federal Institute of Technology (ETH) He studied political science, history and international law at the University of Zurich, where he received an M.A. From 1988 to 1992 he served as a research associate at the United Nations Institute for Disarmament Research (UNIDIR) in Geneva. During that period he wrote a doctoral dissertation analyzing the negotiations on a global chemical weapons ban. In 1992 he received a Ph.D. from the University of Zurich. After two years as postdoctoral research fellow at Harvard University he worked for one year as a senior lecturer in Political Science at the University of Zurich before joining ETH. In his research and teaching, Thomas Bernauer focuses on international economic and environmental issues.

$V$ ally Koubi is a senior researcher at the Center for Comparative and International Studies (CIS) at the Swiss Federal Institute of Technology Zurich (ETH), and a visiting professor at the Institute of Economics at the University of Bern. She studied Public Law and Political Science at the Law School of the University of Athens, Greece (B.A. in 1983). She received an M.S. in Public Policy (1985), an M.A. (1988) and a Ph.D. in Political Science (1991), all from the University of Rochester, USA. From 1991 to 1998 she was an assistant professor at the Department of Political Science of the University of Georgia, USA. She joined the University of Bern and the Center for Comparative and International Studies (CIS) at ETH in 1999. 


\section{About CIS}

The Center for Comparative and International Studies (CIS) Zurich is a research center in the fields of comparative politics and international relations. Launched in 1997 as a joint initiative of the ETH Zurich (Swiss Federal Institute of Technology) and the University of Zurich, the center is made up of several research groups with a total staff of approximately 150. The CIS is the largest institution of its kind in German-speaking Switzerland. CIS members are the Institute of Political Science at Zurich University with chairs in Comparative Politics (Prof. Hanspeter Kriesi), Swiss Politics (Prof Ulrich Klöti and Prof. Daniel Kübler), International Relations (Prof. Dieter Ruloff) and Political Behaviour and Public Opinion (Prof. Sibylle Hardmeier), plus the chairs in International Relations (Prof. Thomas Bernauer and Prof. Jürg M. Gabriel), International Conflict Research (Prof. LarsErik Cederman), International Security Policy (Prof. Andreas Wenger) and Problems of Developing Countries (Prof. Rolf Kappel) at ETH Zurich.

(C) CIS, ETH Zürich / Universität Zürich, 2005

Center for Comparative and International Studies (CIS) Zurich

ETH Zentrum SEI / Seilergraben 45-53

CH-8092 Zürich

Phone +41(0)16327968

Fax $\quad+41(0) 16321942$

cispostmaster@sipo.gess.ethz.ch

www.cis.ethz.ch 